\title{
LOCAL ORIENTATION WISDOM ON THE BUGIS TRADITIONAL HOUSE LAYOUT IN TOSORA VILLAGE, WAJO
}

\author{
Naidah Naing*, Abd Karim Hadi**, Asdar Djamereng*** \\ *) Architecture Study Program, Engineering Faculty, Universitas Muslim Indonesia. \\ **) Civil Engineering Study Program, Engineering Faculty, Universitas Muslim \\ Indonesia. \\ **) Economics Study Program, Economy Faculty, Universitas Muslim Indonesia. \\ e-mail: naidahnaing@yahoo.com
}

\begin{abstract}
Tosora village in Wajo regency-South Sulawesi is the village of the former capital of Wajo Kingdom in the 16th and 17th centuries, which still maintains the arhitecture of Bugis traditional suspended house. The existence of the historic sites such as old mosques, fortresses, Geddong and the natural conditions surrounded by rivers, rice fields and lakes are important in the tradition of building Bugis houses in Tosora. The orientation of the layout and house direction in these traditional settlements is various, so the researchaimed to reveal the guidelines used by Tosora people in determining the orientation of Bugis Traditional houses either based on tradition or other influencing factors. The research methodology used qualitative methods with the Case Study Approach. The research was descriptive and used the analysis method of Discovering Cultural Themes. The results showed that traditionally, the orientation of Bugis house layout was the direction of the houses based on the East wind, the position of the sun on the house and the position of the moon's light into the house. In addition, the orientation is determined by the layout of Bugis house in Tosora which is influenced by the existence of the historic sites (old / ancient mosques and squares) and the location of the houses from rice fields(workplaces) for easy accessibility. The moon symbol as a factor that influences the orientation of the house is different from that in other settlements in Indonesia.
\end{abstract}

Keywords: Orientation, Local Wisdom, Bugis Traditional House

\section{INTRODUCTION}

The Bugis tribes in South Sulawesi are in several areas, such as in Wajo regency, by residing in a traditional suspended house. It is a reflection of Bugis culture. The form and structure reflect the views of the Bugis people in Wajo towards the spatial plan of the universe and human life. In building traditional houses in Wajo, there are two 
important elements taken into account. First, it considers strength and usefulness. Second, the people also consider the spiritual aspects, symbols, and values existing in society. One of the values is in determining the orientation of the Bugis house layout.

The orientation of the house for Bugis people is very important and sacred, where there are several elements used as guidelines for orientation directions, namely mountains, roads, rivers, sun, sea and the wind direction. However, in general the orientation of the Bugis house layout is distinguished into bola mabbuju (longitudinal house) which is a house extending in the East-West direction and bola-mpareq (transverse house) which is extending in the north-south (Sima, 2006).

In addition, the environmental conditions of Tosora Village surrounded by lakes, rivers, and rice fields/gardens have become a part of the development of the house physical culture and community settlements in this village. People live around the historic sites (ancient mosques, fortresses, Geddong and several hundred-year-old graves), around the village center, near rice fields/fields and along the streets of Tosora village. The settlement pattern is linear and the Grid is strongly influenced by the siri' culture adopted by Bugis people. This condition causes Bugis house orientation to have different directions and layouts, such as on water, like Tempe lake and along the WananaE river. The study aims to determine the orientation of Bugis traditional houses in Tosora village, Wajo based on Bugis cultural traditions or other influencing factors. The results of the study are expected to be a reference for local communities in maintaining the tradition of building a Bugis traditional suspendedhouse for the harmony with the natural environment.

\section{THEORY / METHODS}

In Bali, the compass direction is used to orient the houses, where the north direction is shown by the sacred and majestic mount Agung. Likewise, in Bajeng-Gowa, South Sulawesi, the orientation of traditional houses in the entry of Islam also refers to the West and East directions, where the West direction begins to be considered as a sacred direction because of the location of the Muslim qibla. Whereas the East direction is the direction of the rising sun symbolizing fertility and the spirit of life (Idawarni, 2011). This is consistent with what Altman and Chemens (1984) stated that in the cosmology of the Poeblo Indian community in America, they involve eastward, the direction of the sun rises as a highly sacred direction, the sun is considered a "father" which will help the growth of their plants and which will guide the tribe's journey every day in hunting headed to their house in the west.

The orientation of Bugis houses in Tosora Village, Wajo Regency, South Sulawesi is interesting to research because the existence of these traditional settlements cannot be separated from the past history of Tosora Village which was the capital of Wajo Kingdom in the 16th and 17th centuries. The existence of several historic sites in Tosora village, such as the old/ancient mosque, fortifications, Geddong (a kind of savings and loans for ancient community) and several other sites have become a part of the living tradition of Tosora people (Naing, 2011).

The research method used in this study is a qualitative method (Creswell, 2008) 
because the research was conducted in the naturally traditional settlements and still firmly holds to the traditions and customs in building houses. The approach in this study used the Case Study Approach model (Creswell, 2012), with descriptive research (Groat \& Wang, 2002).

\section{Method of collecting data}

The data collection methods in this study use survey, observation, archive/document and interview. The survey was conducted at the research location in Tosora Village, Wajo regency, related to the condition of houses and settlements, the direction and location of houses, existing conditioning of Bugis traditional stage-houses, etc. The observation method was used to collect the physical data of the houses, settlements and the environment around them. Archives/documents were used to collect secondary data in the form of manuscripts, books, research results related to the research, and the interview was used to get the meaning of local wisdom from each symbol, form and activity related to the orientation of Bugis house in Tosora.

The population of the research is the Bugis people who live in Tosora Village, Wajo Regency. The research sample wasdeliberately chosenaccording to the typical houses or settlements that still maintained the characteristics of a traditional stage house. The data was collected for three months.

\section{Data analysis method}

The data analysis method used in this research is the method of Discovering Cultural Themes to reveal the orientation of traditional houses in Tosora. The analysis collected the focus of culture, values and symbols of the physical culture found in the houses and settlements and their relationship with the surrounding environment.

The Discovering Cultural Themes analysis method helped to find the relationships in the symbols of the houseand environment so that a holistic finding on the orientation of the Bugis house was able to determine which was dominant in determining the orientation of the Bugis house in Tosora. Based on the analysis, a reconstruction was prepared in the form of descriptions of influential matters in determining the direction and layout of the Bugis house in Tosora, and then the conclusion was drawn.

\section{RESULTS AND DISCUSSION}

\section{History of the research location}

The research is located in the traditional village of Tosora, Wajo Regency which still maintains the cultural values in living. Tosora is the former capital area of Wajo Kingdomin the 16 th and 17 th centuries, where there are various historical relics ranging from old mosques, defense fortresses of the kingdom, the tomb of the kings of Wajo, and the former warehouse storing the royal ammunition and borrowing goods (Geddong). 
Topographically, Tosora consists of lowlands and hills with altitudes between 18-32 $\mathrm{m}$ above sea level. Tosora hills as the center of Wajo kingdom are surrounded by five lakes, namely Latalibolong, Lababa, Soppengnge, Latanparu and JampuE. There are also a number of small rivers, a stream of WalanaEriver which partially empties into the lake (Naing, 2011). The condition of Tosora village is shown in Figure 1 below.

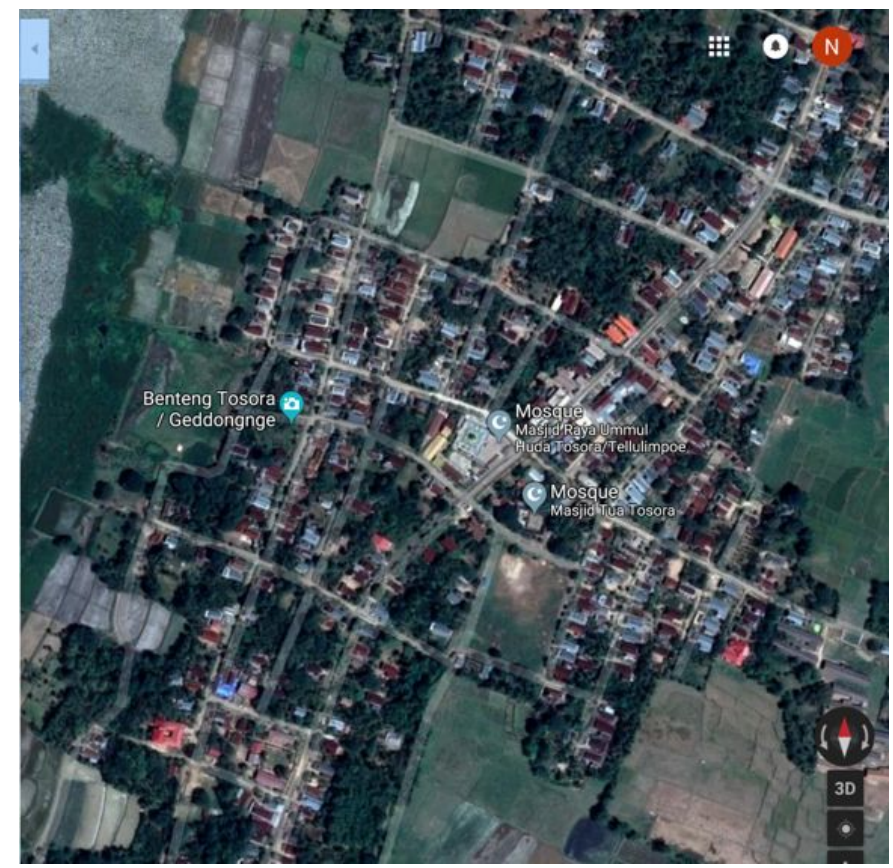

Figure 1. Bugis Traditional Settlements in Tosora Village, Wajo. Source: Google Earth (2018)

Tosora's settlement as a traditional settlement is the forerunner of existing settlements in Wajo Regency today. James Brooke (in Pelras, 2006), during his visit to Tosora in 1840 described the center of Wajo Kingdom in Tosora as a large town with the remains of the collapsed fence surrounding the area with a circumference of several miles. The eastern region is above the hills, while in the West it is down to the swamp. According to Brooke, Tosora is a settlement which is a combination of several villages.

The traditional settlement of Tosora has had a long history until now. The existence of historical sites around the settlements, such as old mosque gives an important meaning to the existence of traditional settlements in Tosora. Theyspread around the mosques and squares. The old mosque of Tosora is the first mosque built in Wajo Kingdom, by Arung Matowa Wajo XV La Pakallongi To Allinrungi in 1621. The remaining building of the mosque is at an altitude of $30.6 \mathrm{~m}$ above sea level, just behind the current Village Office of Tosora, on the south side is the square. The rest of the buildings that are still visible are the mihrab section (niche) on the west side 
that is still intact, while the rest of the wall remains the foundation. The historic sites of the old mosque ruins in Tosora can be seen in Figure 2.

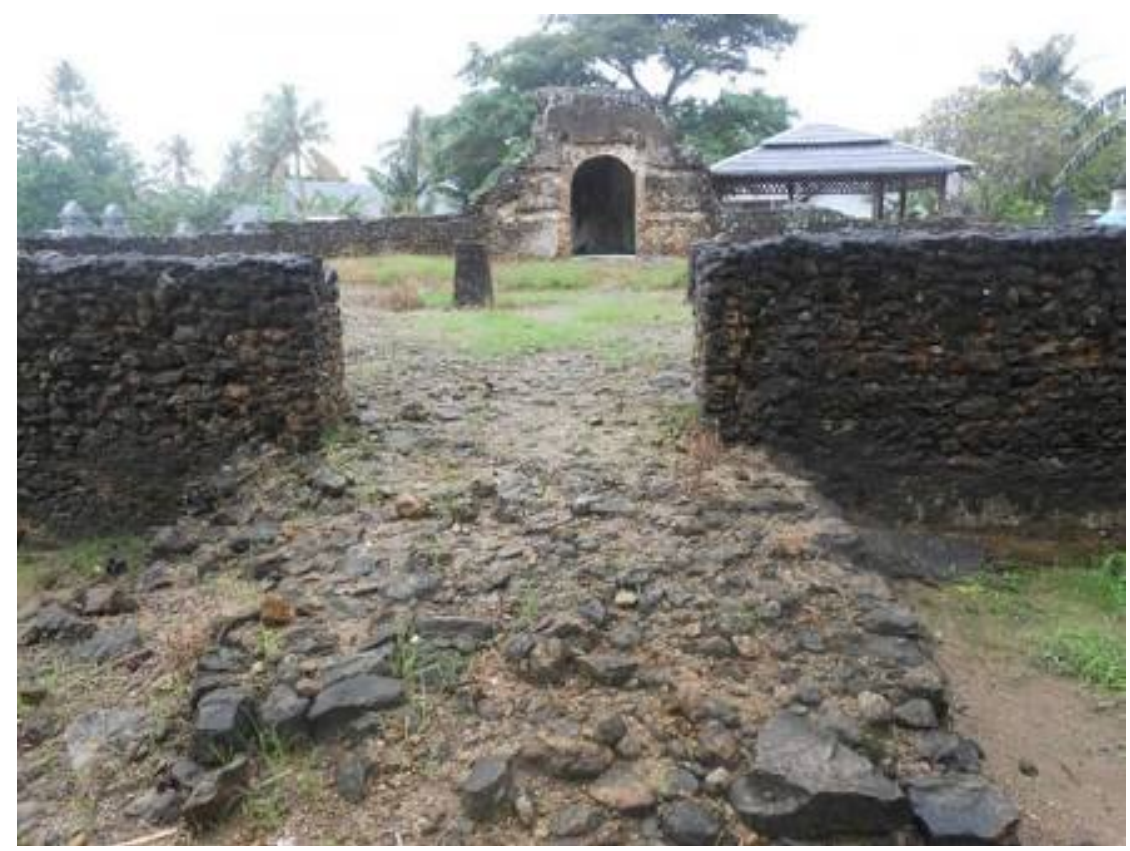

Figure 2. The Historic Site of the Old Mosque in Tosora, Wajo. Built in 1621. Source: Personal Documents (2008)

\section{The orientation of Bugis Houses in Tosora Village, Wajo Regency}

\section{Directions of the Bugis House in Tosora}

Bugis Traditional House has a stage form, with a rectangular floor plan with a saddle roof model. Such form was stated by Mardanas (1985). Stage-house of Bugis tribe reflects physical culture that is built based on the local wisdom of Bugis people who have been handed down from generation to generation. The cosmological understanding of Bugis people based on macrocosm and microcosm influences the form, direction and layout of Bugis houses.

This cosmological understanding likens the Bugis traditional stage-house as the universe and the human body. The house is divided into three parts, the roof (the upper realm, the head on the human body) the body of the house/the middle part of the house (the middle nature, the body of the human) and under the house (the lower realm, the legs of the human body). The form of the Bugis stage house can be seen in Figure 3. 

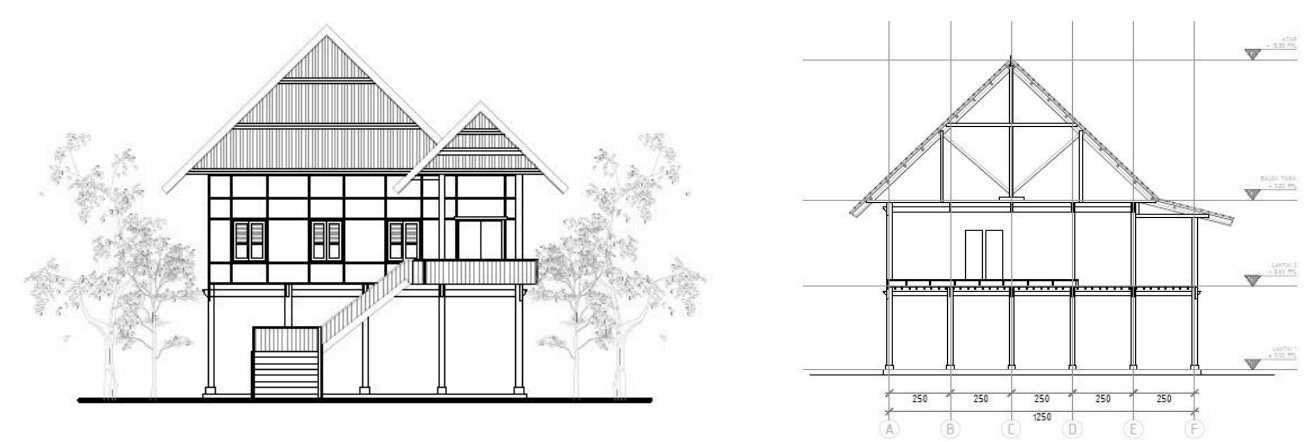

Figure 3. Looks and Pieces of Traditional Bugis Stage Houses in Tosora Village, Wajo. Source: Personal Sketch (2018)

From the interviews, it is found that the direction of the Bugis house in Tosora Village is generally oriented towards East-West according to the direction of the wind. The orientation of the house to the east is due to the local wisdom of the local community because of the people's perception that the East-West direction contains good elements. This is in accordance with several manuscripts written in Bugislontara letters including Lontara kutika, states that the position of the Bugis house related to the land is that the Bugis house is built towards the East. If the land is tilted, the slope should stay away from the front of the house. The sun rising from the East should not be hindered, the house should not be surrounded by high ground (because people will come there to hide). The direction of the Bugis house at Tosora is the same as the tradition of house building in other Austronesian regions.

Lontara'as the guideline manuscripts of Bugis people includes the regularity of the house in the space, the harmony of the house with nature, the relationship balance between human and everyday life.

\section{Wind direction}

Bugis people always use the direction of wind, namely the direction of manorang (North), maniang (South), orai (West), and alau (East), as a pointer to the location or object. In addition, the four directions have a certain meaning, namely: North direction is interpreted as the symbol of death, the South is interpreted as the symbol of worldly life, the West is the holy direction (Qibla), and the East is a symbol of sustenance, based on the direction of the sunrise. The direction of the wind is based on the naming of the Bugis language in Figure 4.

The results of the interview or the view of Panrita Bolain Tosora showed that in a day of the earth rotation ( 24 hours), the sun will end in the North and begin again in the East. So, the best direction of the house is the one of East and West following the wind, the sun and the moon. The wind blowing from East and West is considered not to threaten the position of the house.

The direction of the wind is understood in two perspectives, geographical andastronomical wind. When we are on earth, it will relate to the geographical wind that applies according to the direction of the sunrise and sunset on the horizon. The direction of the sunrise is east and the direction of the sunset is west. The North 
direction is -90 from the east, whereas the south direction is +90 degrees from the east. In one day of the earth rotation ( 24 hours), the sun will end in the south and begin again towards the east. Therefore, in the context of the geographical wind, the beginning and the end of the sun is known as the East-South term.

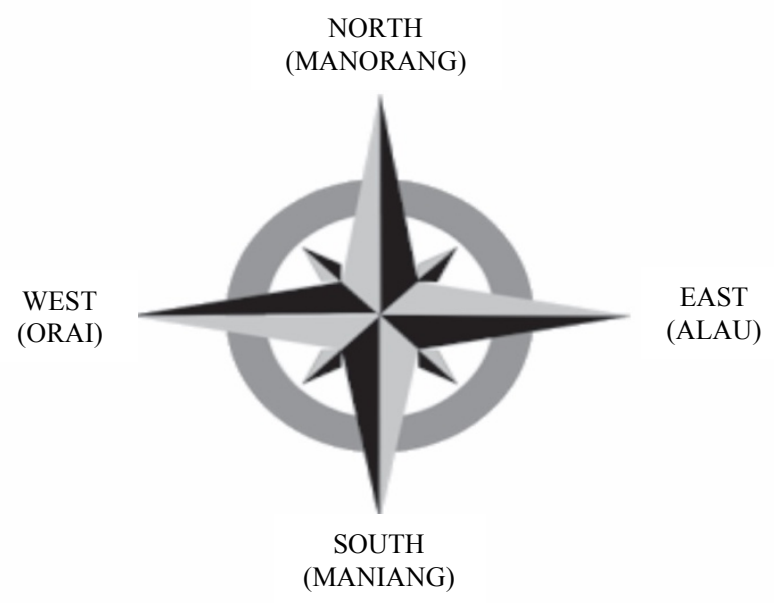

Figure 4. Direction of the wind based on the Bugis naming in Tosora Village, Wajo. Source: Personal Sketch (2018)

However, when it comes out of the earth (the sky) it will be bound by the provisions of the astronomical wind which only applies towards the upper and lower direction of the sky following the daily position of the sun, where the upper one is the direction of the North Sky (above the North pole of the earth) and the lower is the direction of the South Sky(above the South pole of the earth). So, in one day of the earth rotation, the sun will end in the North (Nimlocana) and begin again in the east (Devadhani). So, it is believed that the direction of a good house is in the east where the sun shines again. The House orientation based on the wind in Tosora seen in Figure 5.

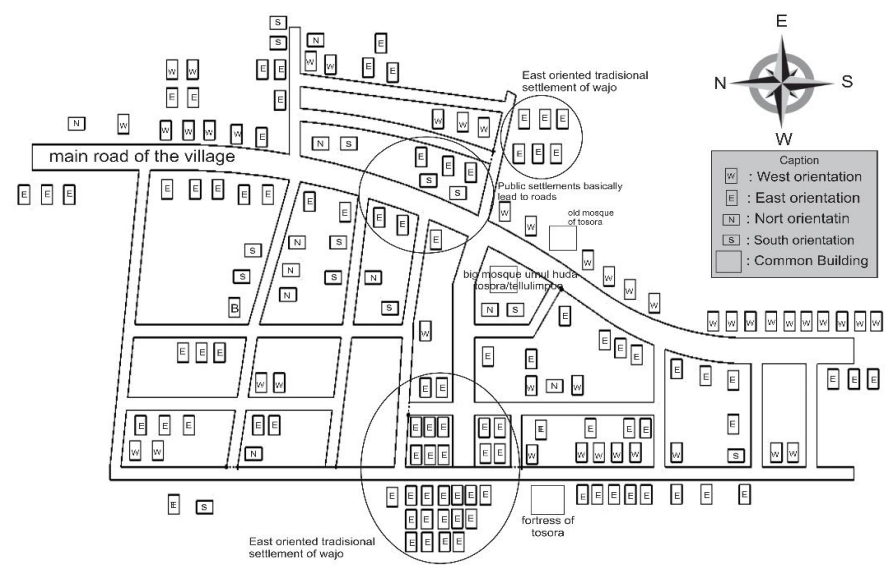

Figure 5. The orientation of Bugis House based on the wind in Tosora, Wajo. Source: Personal Sketch (2018) 
In Bugis traditional house layout, there are clean and less clean (dirty)rooms. The roomsconsidered as the clean one includes: the living room, family room, and bedroom which are usually placed in the West or South direction. Whereas the rooms considered dirty include: the main circulation room of the house, kitchen, and service rooms (toilet, corpse bathing room, laundry room, and lego-lego) which are usually placed in the East or North directions.

\section{Position of the Sunlight}

The determining factor of the direction of Bugis house in Tosora is the position of the sun. Morning sun is very good for health and the light is good for the house, so the habit of widely opening the doors and windows aims to let the sunlight break into the house. The people in Tosora believe that sunlight coming into the house will make the house not bleak, far from all diseases and can be used as a guidelinein building a new house. The position of the house on the sun catchment can be seen in Figures 6 and 7 .

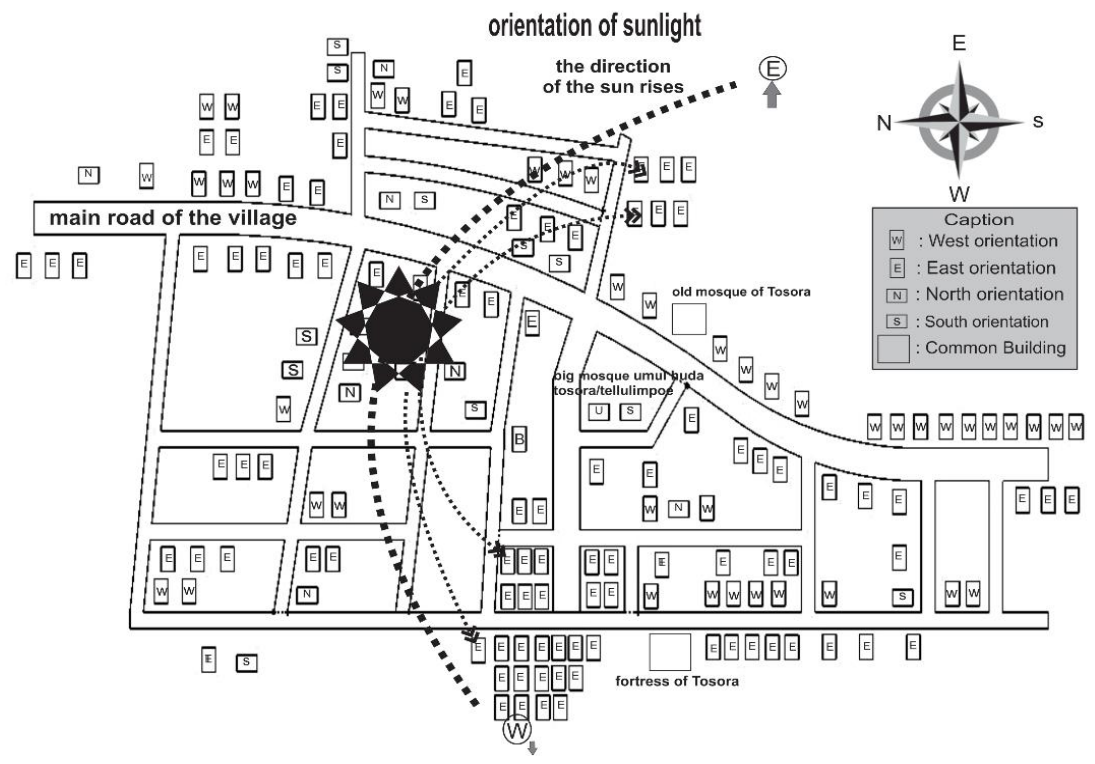

Figure 6. The direction of the Bugis house based on the sun catchment in Tosora, Wajo Source: Personal Sketch (2018) 


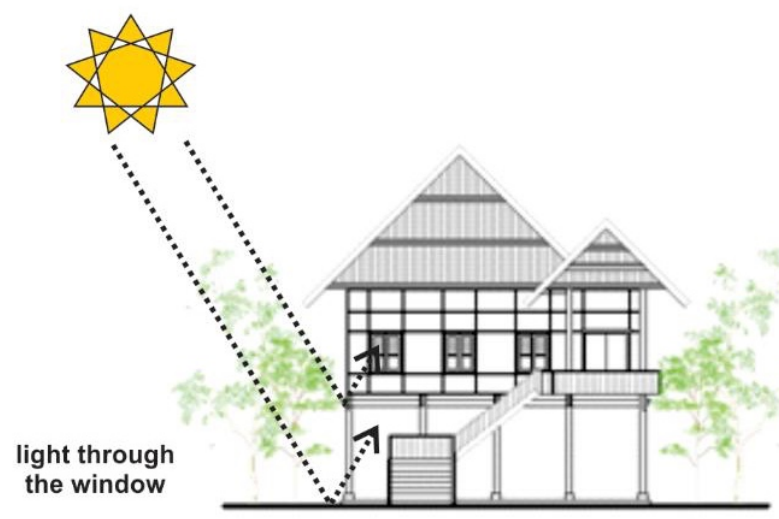

Figure 7. The position of the sun on the Bugis House in Tosora, Wajo Source: Personal Sketch (2018)

\section{Position of the Moonlight}

Besidessunlight, the moon is also used as a guide to the direction of the house. The full moon light that can directly break into the house is considered the best position for the house. This view assumes that moonlight contains nectar that is good for health. Houses containing nectar are assumed to bring happiness for the owner. The moonlight at night breaking through the windows and doors causes people to tend to open their doors and windows widely while chatting in front of the house. The illustration can be seen in the following Figures 8 and 9 .

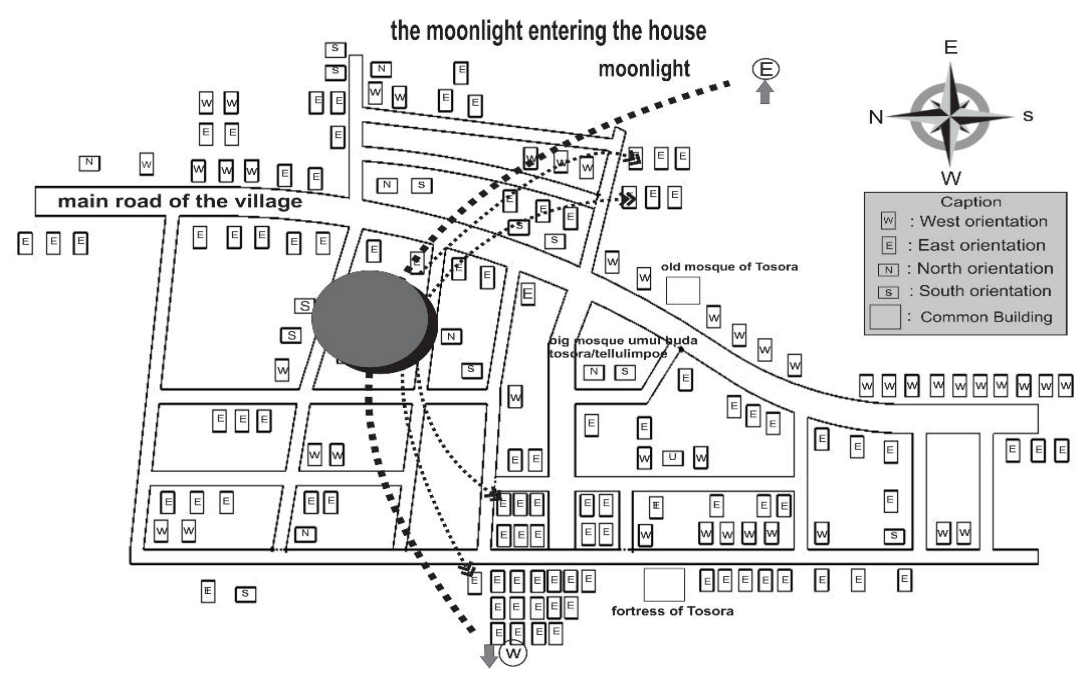

Figure 8. Direction of the Bugis House based on the capture of the Moon's light in Tosora, Wajo.

Source: Personal Sketch (2018) 


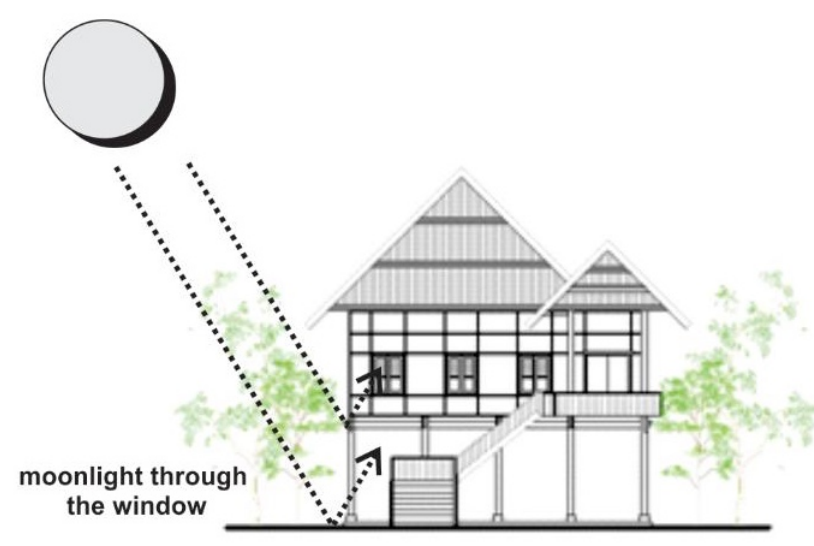

Figure 9. Position of the Moonlight on the Bugis House in Tosora, Wajo. Source: Personal Sketch (2018)

\section{Location of the Bugis House in Tosora}

The Bugis house in Tosora is based on the culture and understanding of the local community that an ideal house is a long rectangular shape. This is based on the understanding of the Bugis cosmology that everything is considered perfect if it has four sides, including the shape of the ground where the house is placed.

This is in line with what Robinson (2005) pointed out that according to the noncataloged manuscript / Lontara'Rappang, the ideal quality of the ground is seen in color, smell and taste, while the ideal shape of the land is a rectangle with a width shorter than its length. If the width is greater than the length it is considered not good. This condition affects the position of the house on the road, namely the position of mangolo (wide direction facing the road) and Mpareq (long direction facing the road).

This shows that the local wisdom of Bugis community on the macrocosm has already been applied to the placement of their house since a long time ago. The Bugis manuscript has connected the luck, welfare, health, and future of the Bugis homeowner with the direction and location of the house, as found in the tradition of other house orientations in Indonesia.

For Bugis community in Tosora, the proper placement of the house is expected to give happiness to the owners. Therefore, in choosing a house placement, it is a must to ask for theexpert in building a house (panrita bola). The location of the Bugis house cannot be in the direction of the grave, so the location of the house may not be longitudinal (Mangolo) from North to South. The location in the direction of the grave is believed to result in continuous disasters to its dwellers.

\section{Location of the Houses around the Old Mosque}

The houses in Tosora are around the OldMosque Site, the Grand Mosque and around the ancient fortresses/Geddongge. The placement of the house along the neighborhood follows the direction of the wind, the Sun and the Moon. The direction facing the road is not a considered important in placing a house on the site. However, the East-West 
direction is the main consideration in the placement of houses on the roadside. Only a small part of the house is placed on the side of the road facing North-South. Therefore, a number of roads facing towards North-South are not used as the location for the houses in Tosoraas Figure 10 below.

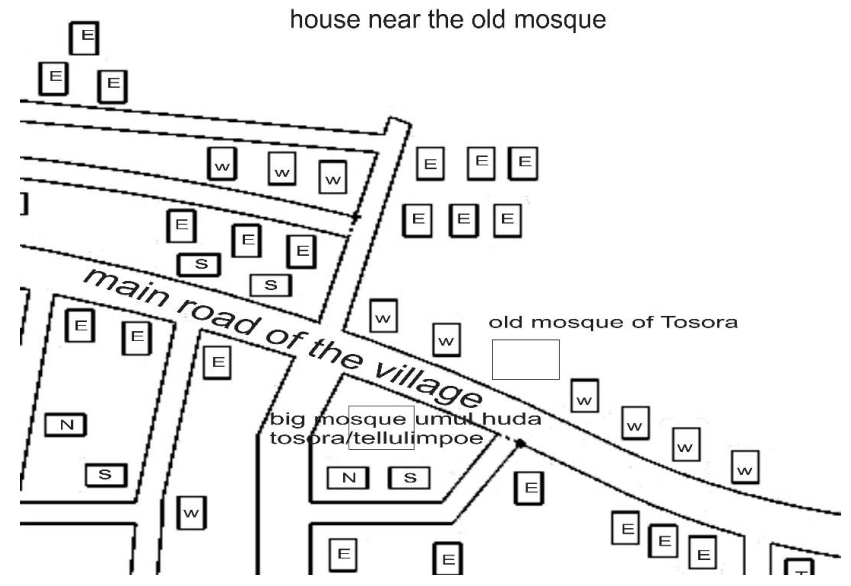

Figure 10. Location of the Bugis House Around the Old Mosque in Tosora Village, Wajo. Source: Personal Sketch (2018)

The existence of the Old Mosque as a historic site affects the location of houses in Tosora Village. This is related to the history of the entry of Islam in Tosora. In the 17 th century Tosora was situated by the location of a settlement inside the fortress where there were also Geddong (ammunition warehouses), old mosques and squares. The presence of Sayyid Jamaluddin Al-Akbar Al-Husaini in Wajo who is still the grandson of the Prophet's descendant in Wajo in 1320, has the title of Syechta Tosora, meaning our Syech in Tosora, marked by the tomb of Syechta Tosora, is the evidence of the entry of Islam in Wajo, especially Tosora as the capital of Wajo Kingdom. The existence of mosques and squares as the center of the religious activities causes people to be oriented and live near mosques and squares. However, the settlements in Tosora today are not only around the historic sites of oldmosques but also develop and spread around the old city center, near public facilities, along the road and close to the rice fields / gardens.

\section{Location of the house near the rice fields}

The Bugis people in Tosora are mostly farmers. Agricultural activities are the main livelihood of the Wajo Society from the 13th century to the present. This is marked by the findings of 36 mortar on the three biggest sites in Wajo, namely Cilellang, Tobattang and Allangkanangesites. Some symbols/ornaments from the Bugis stage house illustrate the livelihoods of the people. Suchas the use of pineapple carvings on ornamental beams under the roof, window ornaments or walls carved in the form of fruits and flowers. 
The people who make a living as farmers, generally choose to live near the ricefields/gardens. They are located around the settlement area, in the North, South and also the West. The location of work-oriented houses (rice fields, gardens) will facilitate accessibility to the workplace. The location of the house near the rice field / work place is shown in the following Figures 11 and 12.

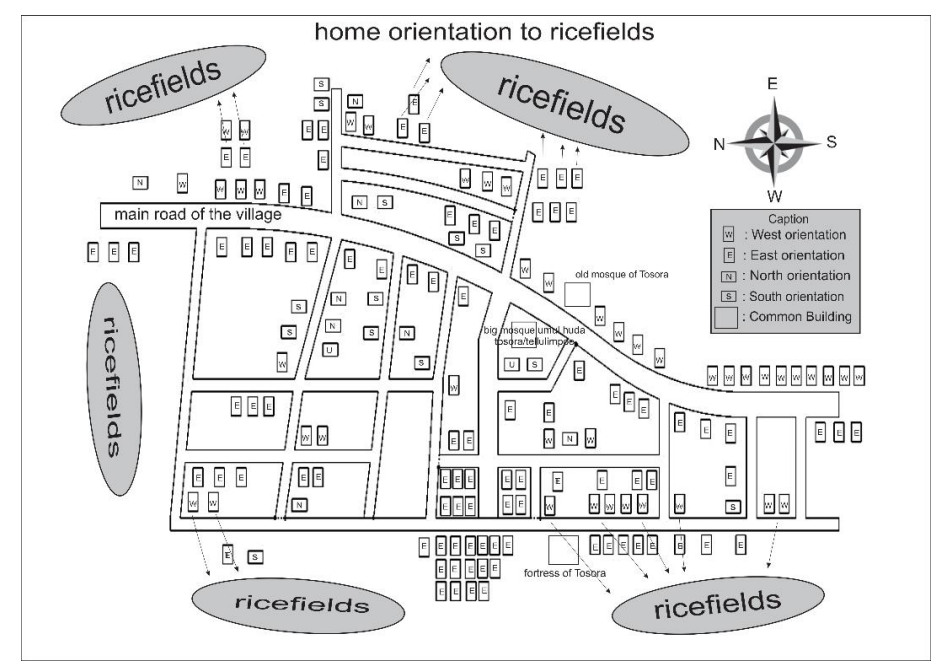

Figure 11. Location of Bugis House around the Field / Garden in Tosora Village, Wajo. Source: Personal Sketch (2018)

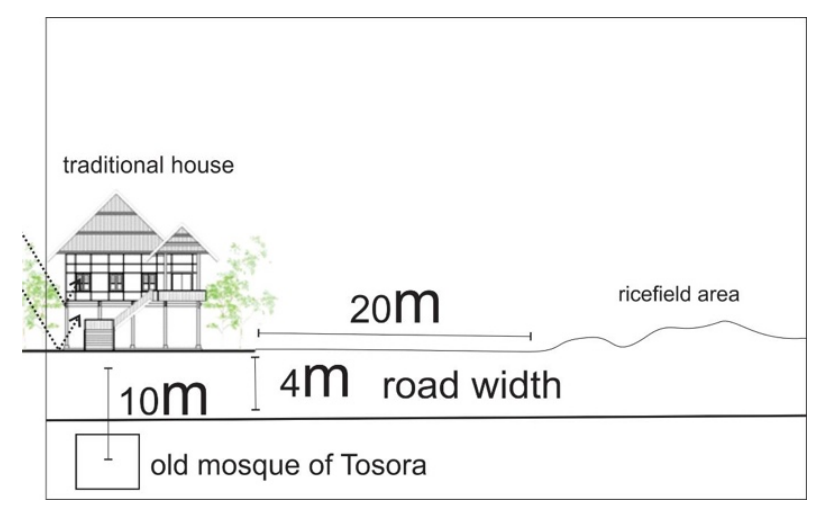

Figure 12. The average distance from the Bugis House to rice fields / gardens and old mosques in Tosora Village, Wajo.

People living near rice fields / workplaces live in groups based on kinship systems, either as blood-related family or friendship relation. The people tend to settle together with large families who have family ties to make it easier to cultivate rice fields individually or in mutual cooperation. This is the same as the people of Salarang village, Bone (Wikantari, 2011). The cultivation system through mutual cooperation in Tosora affects the placement of houses. For the people in Tosora, rice fields are a source of life. The illustration can be seen in Figure 13. 


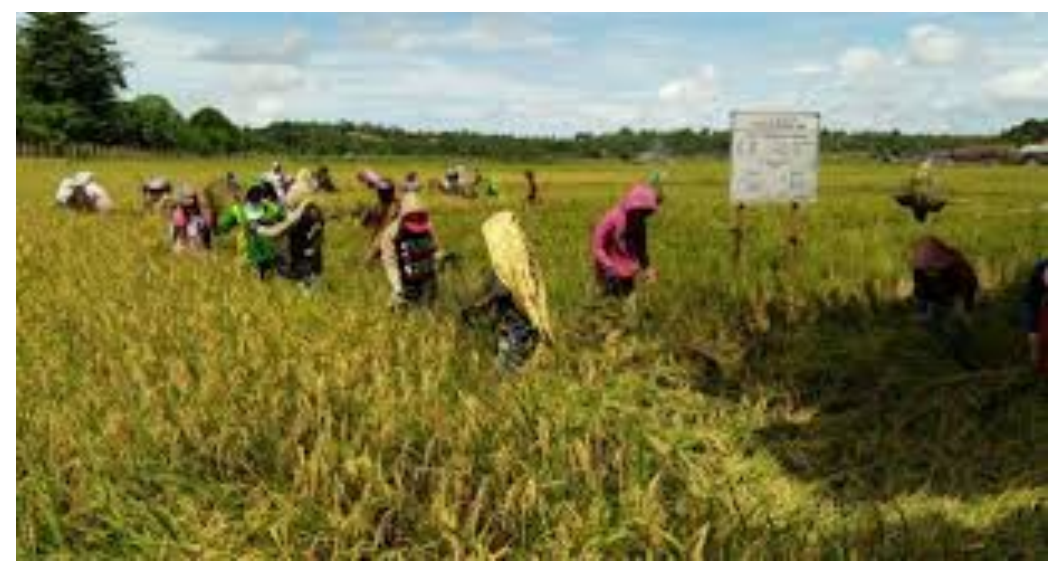

Figure 13. Rice fields as a source of life in Tosora Village, Wajo. Source: Personal Documents (2018)

\section{CONCLUSION}

The Bugis traditional house orientation in Tosora such as direction and layoutconsiders traditions and other factors that influence the orientation. The tradition factor in determining the direction of the house in Tosora generally refers to the direction of the wind, sun and moon. According to the Bugis tradition, the best direction is the direction of Alau' (East) because the people believe that it is the best direction for the house although there are a small number of directions facing the house towards the West and North. Besides, the direction of the sun in the morning and the moonlight at night shining through the doors and windows is considered a good direction to make the house bright. Based on this reason the Bugis people in Tosora always open the doors and windows wide during the day and night.

Other factors influencing the layout of the Bugis stage house in Tosora are based on the proximity to the historic sites of the Old Mosque and the square so that the people choose to live near the center of religious activities. In addition, the placement of the house is also based on the proximity to the workplace / rice field to facilitate accessibility from home to the workplace with the position of mangolo (the width direction leads to the road). The consideration of the moonlight element in determining the house orientation in Tosora is different from that in other Bugis traditional houses in Indonesia.

\section{REFERENCES}

Creswell, J.W. (2008) Research Design: Qualitative, Quantitative, and Mixed Methods Approaches. California: Sage Publications, Inc.

Groat, L. \& Wang, D. (2002) Architectural Research Methods. New York: John Wiley \& Sons. Inc. 
Irwin Altman and Martin Chemers. (1989) Culture and Environment. Cambridge University Press

Idawarni. (2011) Penentu Arah dan Letak Permukiman dan Rumah Tinggal Kaitannya dengan Kosmologi, Studi Kasus : Kampung kanarea, Kecamatan bajeng Gowa Sulawesi Selatan. Local Wisdom -Jurnal Ilmiah online, ISSN: 20863764. Volume: III, nomor:1, Hal 09-18.

Mardanas, Izarwisma,. (1985) Arsitektur Tradisional Daerah Sulawesi Selatan. Jakarta : Dep P dan K.

Naing, Naidah. (2011) Wajo dalam Perspektif Arsitektur. Makassar : Pustaka Refleksi.

Pelras, Christian. (2006) Manusia Bugis. Jakarta: Penerbit Nalar.

Wikantari, dkk., (2011) Faktor penentu Orientasi Rumah di Permukiman Nelayan Dusun Salarang Kabupaten Maros. Prosiding

Hasil-Hasil Penelitan Fakultas Teknik. Volume: 5, Desember 2011. ISSN : 978-979127255-06 